\author{
Huda S. Abed \\ Northern Technical \\ University ,Technical College \\ of Mosul \\ Iraq, Mosul \\ Techcol.mosul@ntu.edu.iq
}

Received on: $25 / 06 / 2018$

Accepted on: 08/11/2018

Published online: 25/01/2019

\section{Production of Lightweight Concrete by Using Construction Lightweight Wastes}

Abstract- This research covers the use of cellular lightweight concrete waste as recycled coarse aggregates to produce lightweight concrete. Various volume fractions of coarse aggregate (35\%, 50\%, and 75\%) were used. The specimens were tested for compressive strength and density at age of 28-days. The compressive strengths for the resulting lightweight concrete with a density of $(2131,1826$ and 1630$) \mathrm{kg} / \mathrm{m}^{3}$ were $(24,22.6$ and 11.5$) \mathrm{MPa}$, respectively. In addition, silica fume was utilized as a constant replacement ratio $6 \%$ of cement weight for mixes lightweight aggregate to enhance the compressive strength of such concrete.

Keywords-Lightweight concrete; Cellular concrete aggregates and Strength

How to cite this article: H.S. Abed, "Production of Lightweight Concrete by Using Construction Lightweight Wastes". Engineering and Technology Journal, Vol. 37, Part A, No. 1, pp. 12-19, 2019.

\section{Introduction}

Lightweight concrete has utilized in buildings for over 93 years [1]. Structural lightweight concrete has a density varied from 1440 to $1840 \mathrm{~kg} / \mathrm{m} 3$ compared to normal weight concrete with a density was varied from 2240 to $2400 \mathrm{~kg} / \mathrm{m} 3$. The compressive strength of concrete must be maximal than $17.0 \mathrm{MPa}$, for structural applications. Use lightweight concrete leads to decrease the size of columns, footings and less reinforcing steel due to the decrease of the dead load of the structure of the concrete. Structural lightweight concrete fits a larger fire-rated concrete structure [2]. A combination of fine lightweight aggregate and coarse lightweight aggregate or coarse lightweight aggregate and normal weight fine aggregate can be used to manufacture Lightweight concrete [2]. Some of the researchers have been used the lightweight aggregates that were produced from a variety of source materials including pumice, expanded shale, and clay [3, 4, 5 and 6]. The construction of lightweight waste is very useful to produce lightweight concrete, in addition, the environmental pollution would be reduced. The wastes producing from the construction and destruction of buildings, and civil works infrastructure that can be called waste construction [7]. Many researchers have conducted intensive studies [7,8 and 9] on the utilize of construction wastes as recycled lightweight aggregates such as fractions of cellular concrete, porcelanite and sawdust. The results showed a decrease in density, compressive strength and splitting strength. Therefore, carbon fiber, silica fume, and other material were inserted to improve the compressive strength and splitting strength of lightweight concrete. Thanon
Dawood and others [10] used the carbon fibers for strengthening the foamed concrete. They concluded that the compressive strength increased from 17.1MPa to $23.1 \mathrm{MPa}$ when used of $1 \%$ of carbon fiber as a volumetric fraction. Ganesh Babu and SaradhiBabu [11] and GonzálezFonteboa and Martínez-Abella [12] investigated the use of polystyrene beads and destruction waste as the lightweight aggregate with the insertion of silica fumeat different ratios. The results showed a variation in the density of the concrete form 1500 to $2000 \mathrm{~kg} / \mathrm{m} 3$, with the corresponding to strengths varied from 10 to 21 $\mathrm{MPa}$. The amount of strength earning for concretes shows an increase when increasing the ratios of silica fume. González Fonteboa, MartínezAbella [12] executed experiments to determine the density, grading, water absorption, flakiness index and shape index. Chen and Liu [13] concluded that the partially substituting fine and coarse aggregate by expanded polystyrene beads made to a density of $800-1800 \mathrm{~kg} / \mathrm{m} 3$ and a compressive strength of $10-25 \mathrm{MPa}$. The Interconnection between the expanded polystyrene beads and cement was improved by fine silica fume and led to increasing the compressive strength. In addition, the drying shrinkage was improved by adding fiber of steel.

In this paper, the effect of using the cellular concrete waste as a recycled aggregate on the density, absorption, thermal conductivity, compressive, flexure, splitting strengths of concrete is studied by replacing coarse aggregate with different percentages of recycled cellular concrete keeping the silica fume ratio constant $6 \%$. For all mixes, compressive, flexure and 
splitting strengths were determined at age of 28 days.

\section{Materials and Mix Proportions}

\section{Materials}

The cement used in mortar mixtures was Ordinary Portland Cement (OPC) produced by Sinjar Factory (Mosul). The chemical, mechanical and physical characteristics of ordinary Portland cement are shown in Table 1 and 2 such characteristics are confirmed to IQS: 5/1984 [14]. Silica fume (Sika Fume HR) was used at a constant replacement ratio of $6 \%$ of cement weight, the physical composition of silica fume are given in Table 3, the chemical composition is shown in Table 4 and agreeing to ASTM-C 1240 [15]. The fine aggregate was natural sand with a fineness modulus of 2.86 the sieve analysis for sand agreeing to ASTM C330/03 [16] and shown in Table 5. Natural coarse aggregate was used riverbed gravel obtained from River Tigris (Mosul/Iraq), the sieve analysis for gravel to ASTM C330/03 [16] and shown in Table 6. Cellular concrete wastes are used as a coarse aggregate by crushing these wastes, Figure 1 shows the crushed cellular concrete aggregates used in this study. The sieve analysis of coarse cellular concrete aggregates agreeing to ASTM C330 [17] and shown in Table 7. The bulk density and absorption capacity for the cellular concrete aggregates were $413 \mathrm{~kg} / \mathrm{m}^{3}$ and $88.7 \%$ respectively these tests achieved according to ASTM C796 [18], tap water was used at a constant ratio $0.45 \%$.

Table 1: Chemical Composition of Cement

\begin{tabular}{lll}
\hline \hline Constituent & $\begin{array}{l}\text { Portland } \\
\text { cement } \\
\% \text { by } \\
\text { weight }\end{array}$ & $\begin{array}{l}\text { Limits of } \\
\text { IQS: } \\
5 / 1984 \\
{[14]}\end{array}$ \\
\hline Lime $(\mathrm{CaO})$ & 62.55 & - \\
\hline Silica $(\mathrm{SiO} 2)$ & 21.52 & - \\
\hline Alumina $(\mathrm{Al2O} 3)$ & 5.6 & - \\
\hline Iron oxide $(\mathrm{Fe} 2 \mathrm{O} 3)$ & 2.74 & - \\
\hline Magnesia $(\mathrm{MgO})$ & 3.23 & $\leq 5.0 \%$ \\
\hline $\begin{array}{l}\text { Sulphur trioxide } \\
\text { (SO3) }\end{array}$ & 2.44 & $\leq 2.8$ \\
\hline $\mathrm{C} 3 \mathrm{~S}$ & 42.52 & - \\
\hline $\mathrm{C} 2 \mathrm{~S}$ & 29.87 & - \\
\hline C3A & 10.2 & - \\
\hline C4AF & 8.33 & - \\
\hline $\begin{array}{l}\text { Loss on ignition } \\
\text { (L.O.I.) }\end{array}$ & 1.5 & $\leq 4.0 \%$ \\
\hline $\begin{array}{l}\text { Insoluble residue } \\
\text { (I.R.) }\end{array}$ & 0.4 & $\leq 1.5 \%$ \\
\hline
\end{tabular}

Table 2: Physical Properties of Cements

\begin{tabular}{lll}
\hline \hline $\begin{array}{l}\text { Physical } \\
\text { properties }\end{array}$ & Results & $\begin{array}{l}\text { Limits of IQS: } \\
5 / 1984[14]\end{array}$ \\
\hline $\begin{array}{l}\text { Initial setting } \\
\text { time (minute) }\end{array}$ & 80 & $\geq 45$ minute \\
\hline $\begin{array}{l}\text { Final setting } \\
\text { time (minute) }\end{array}$ & 240 & $\leq 600$ minute \\
\hline $\begin{array}{l}\text { Fineness } \\
\left.\text { Blaine } \mathrm{m}^{2} / \mathrm{kg}\right)\end{array}$ & 310 & $\geq 230(\mathrm{~m} 2 / \mathrm{kg})$ \\
\hline $\begin{array}{l}\text { Soundness by } \\
\text { Autoclave }\end{array}$ & 0.05 & Not more than 0.8 \\
Method (\%) & & \\
\hline $\begin{array}{l}\text { Compressive } \\
\text { strength (MPa) }\end{array}$ & 21 & $\geq 15$ \\
3 days & 27 & $\geq 23$ \\
7 days & & \\
\hline
\end{tabular}

Table 3: Physical Properties of Silica fume

\begin{tabular}{ll}
\hline \hline Form & Agglomerated \\
\hline $\begin{array}{l}\text { Particles Color/ } \\
\text { Appearance }\end{array}$ & Grey \\
\hline Specific Gravity & 2.20 \\
\hline Size of particles & $0.1 \mu$ \\
\hline Dosage & $\begin{array}{l}2-10 \% \text { by weight of } \\
\text { cement }\end{array}$ \\
\hline Chloride content & Nil \\
\hline
\end{tabular}

Table 4: Chemical Composition of Silica fume

\begin{tabular}{lll}
\hline \hline Constituent & $\begin{array}{l}\text { Silica fume(SF) } \\
\% \text { by weight }\end{array}$ & $\begin{array}{l}\text { Limits of } \\
\text { ASTM-C } \\
1240[15]\end{array}$ \\
\hline Lime $(\mathrm{CaO})$ & 0.89 & - \\
\hline Silica $(\mathrm{SiO} 2)$ & 91.3 & $\geq \% 85.0$ \\
\hline $\begin{array}{l}\text { Alumina } \\
\text { (Al2O3) }\end{array}$ & 0.66 & - \\
\hline $\begin{array}{l}\text { Iron oxide } \\
\text { (Fe2O3) }\end{array}$ & 0.3 & - \\
\hline $\begin{array}{l}\text { Moisture } \\
\text { content }\end{array}$ & 1.5 & $\leq \% 3.0$ \\
\hline $\begin{array}{l}\text { Loss on } \\
\text { ignition }\end{array}$ & 2 & $\leq \% 6.0$ \\
\hline
\end{tabular}

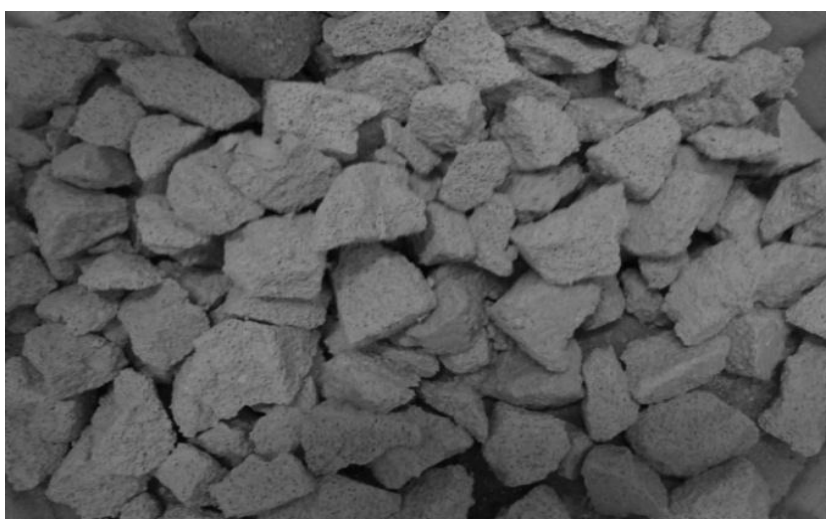

Figure 1: Crushed Cellular Concrete Aggregates 
Table 5: Sieve analysis for sand

\begin{tabular}{lll}
\hline \hline Sieve mm & \% Passing & $\begin{array}{l}\text { Limits of ASTM } \\
\text { C330/03 [16] }\end{array}$ \\
\hline 9.5 & 100 & 100 \\
\hline 4.75 & 96 & $95-100$ \\
\hline 2.36 & 91 & $80-100$ \\
\hline 1.18 & 77 & $50-85$ \\
\hline 0.6 & 38 & $25-60$ \\
\hline 0.3 & 9.8 & $5-30$ \\
\hline 0.15 & 2.6 & $0-10$ \\
\hline pan & 0 & 0 \\
\hline
\end{tabular}

Table 6): Sieve analysis for gravel

\begin{tabular}{lll}
\hline $\begin{array}{l}\text { Sieve } \\
\mathrm{mm}\end{array}$ & \% Passing & $\begin{array}{l}\text { Limits of ASTM } \\
\text { C330/03 [16] }\end{array}$ \\
\hline 37.5 & 100 & 100 \\
\hline 25 & 93 & $90-100$ \\
\hline 19 & 57.8 & $40-85$ \\
\hline 12.5 & 19 & $10-40$ \\
\hline 9.5 & 0 & $0-15$ \\
\hline 4.75 & 0 & $0-5$ \\
\hline pan & 0 & 0 \\
\hline
\end{tabular}

Table 7: Sieve Analysis of Coarse Cellular Concrete Aggregates

\begin{tabular}{lll}
\hline \hline Sieve designation & $\begin{array}{l}\text { Percentage (Mass) Passing Sieves Having Square } \\
\text { Openings \% (ASTM C330) [17] }\end{array}$ & $\begin{array}{l}\text { Percentage (Mass) Passing Sieves } \\
\text { Having Square Openings \% }\end{array}$ \\
\hline $25 \mathrm{~mm}$ & 100 & 100 \\
\hline $19 \mathrm{~mm}$ & $90-100$ & 91 \\
\hline $12.5 \mathrm{~mm}$ & & \\
\hline $9.5 \mathrm{~mm}$ & $10-50$ & 42 \\
\hline $4.75 \mathrm{~mm}$ & $0-15$ & 0 \\
\hline $2.36 \mathrm{~mm}$ & $\ldots$. & \\
\hline $1.18 \mathrm{~mm}$ & $\ldots$. & \\
\hline $300 \mathrm{~mm}$ & $\ldots$. & \\
\hline $150 \mathrm{~mm}$ & $\ldots$. & \\
\hline
\end{tabular}

Table 8: Concreter mix proportions

\begin{tabular}{|c|c|c|c|c|c|c|}
\hline Index & $\begin{array}{l}\text { Cement } \\
\mathrm{kg} / \mathrm{m}^{3}\end{array}$ & $\begin{array}{l}\text { Water } \\
\mathrm{kg} / \mathrm{m}^{3}\end{array}$ & $\begin{array}{l}\text { Percentage of } \\
\text { cement weight } \\
\text { replacement \% by } \\
\text { silica fume }\end{array}$ & $\begin{array}{l}\text { Sand } \\
\mathrm{kg} / \mathrm{m}^{3}\end{array}$ & $\begin{array}{l}\text { Percentage of coarse aggregate } \\
\text { replacement }(\%) \text { by volume of } \\
\text { recycle cellular concrete } \\
\text { aggregates }\end{array}$ & $\begin{array}{l}\text { Coarse } \\
\text { aggregate } \\
\mathrm{kg} / \mathrm{m}^{3}\end{array}$ \\
\hline A1 & 405.5 & 174 & 0 & 608.3 & 0 & 1216.7 \\
\hline $\mathrm{A} 2$ & 405.5 & 174 & 6 & 608.3 & 35 & 791 \\
\hline A3 & 405.5 & 174 & 6 & 608.3 & 50 & 608.3 \\
\hline A4 & 405.5 & 174 & 6 & 608.3 & 75 & 304 \\
\hline
\end{tabular}

\section{Mix proportions}

Details of the mix proportions for the concrete containing different levels of cellular concrete aggregates are given in Table 8. The control mix was cast using normal aggregate without using silica fume $(0 \% \mathrm{SF})$ with mix proportion $(1: 1.5$ : 3: 0.45$)$ by weight. While the other mixes were designed by substituting part of the coarse aggregates with coarse cellular concrete aggregates at three different replacement levels on a volume-for volume basis (according to the volumetric fraction). The percentages of coarse cellular concrete aggregates replacements were $35 \%, 50 \%$, and $75 \%$. The silica fume was added to the three mixes that have coarse cellular concrete aggregates with a constant value of replacement $6 \%$ by weight of cement.

\section{Casting, Curing and Testing of Concrete Specimens}

For each concrete mixture, three $150 \times 300 \mathrm{~mm}$ concrete cylinders were used to test the splitting strength according to ASTM C496 [19], testing of bulk density and moist density for different concrete mixes according to ASTM C567 [20], and the absorption test for all mixes are achieved according to ASTM C642 [21]. Testing of the flexural strength of the specimens was conducted on three $100 \times 100 \times 400 \mathrm{~mm}$ samples in accordance with to ASTM C78 [22]. Also, three $150 \mathrm{~mm}$ cubes were used to test the compressive strength according to British standard BS 1881: Parts 116 [23]. The specimens were taken away from moulds 24 hours after casting and were put in the water at $23 \pm 2{ }^{\circ} \mathrm{C}$. The compressive strength, flexural strength and splitting strength samples were tested at age of 28 days. Each strength value was the average of strength for three specimens. 


\section{Results and Discussion}

I. Bulk density, moist density, and rate of absorption:

The density reduced by increasing the percentage of cellular concrete aggregate, various volume fractions of replacing the natural coarse aggregate $(35 \%, 50 \%$ and $75 \%)$ by cellular concrete aggregate lead to decrease the bulk density by $(14 \%, 26.3 \%$ and $34.2 \%)$ respectively as shown in Table 9 and Figure 2.

This reduction in density is due to the fact that cellular concrete aggregate is lighter than the natural coarse aggregate. Also, the replacing led to increasing the rate of absorption from $62.9 \%$ to $291.4 \%$ as shown in Table 9 and Figure.3, due to the higher capacity of absorption of cellular aggregate than the natural coarse aggregate. Figure 4 and Figure 5 denote that the moist density of concrete is larger than the bulk density for the same mix and the amount of difference between bulk density and moist density is increased by decreasing the bulk density for all mixes due to high water absorption capability of cellular aggregate.

Table 8: Concreter mix proportions

\begin{tabular}{lllllll}
\hline \hline Index & $\begin{array}{l}\text { Cement } \\
\mathrm{kg} / \mathrm{m}^{3}\end{array}$ & $\begin{array}{l}\text { Water } \\
\mathrm{kg} / \mathrm{m}^{3}\end{array}$ & $\begin{array}{l}\text { Percentage of } \\
\text { cement weight } \\
\text { replacement } \% \text { by } \\
\text { silica fume }\end{array}$ & $\begin{array}{l}\text { Sand } \\
\mathrm{kg} / \mathrm{m}^{3}\end{array}$ & $\begin{array}{l}\text { Percentage of coarse } \\
\text { aggregate replacement } \\
(\%) \text { by volume of recycle } \\
\text { cellular concrete aggregates }\end{array}$ & $\begin{array}{l}\text { Coarse } \\
\text { aggregate } \\
\mathrm{kg} / \mathrm{m}^{3}\end{array}$ \\
\hline $\mathrm{A} 1$ & 405.5 & 174 & 0 & 608.3 & 0 & 1216.7 \\
\hline A2 & 405.5 & 174 & 6 & 608.3 & 35 & 791 \\
\hline A3 & 405.5 & 174 & 6 & 608.3 & 50 & 608.3 \\
\hline A4 & 405.5 & 174 & 6 & 608.3 & 75 & 304 \\
\hline
\end{tabular}

Table 9: Effect of replacing the natural coarse aggregate by recycle cellular concrete coarse aggregate on bulk density, moist density and absorption

\begin{tabular}{llllll}
\hline \hline Index & $\begin{array}{l}\text { Bulk } \\
\text { density } \\
\mathrm{kg} / \mathrm{m}^{3}\end{array}$ & $\begin{array}{l}\text { Saturated surface } \\
\text { dry(SSD) } \\
\text { density } \mathrm{kg} / \mathrm{m}^{3}\end{array}$ & $\begin{array}{l}\text { Decrease in } \\
\text { Density (\%)with } \\
\text { respect to A1 }\end{array}$ & $\begin{array}{l}\text { Rate of } \\
\text { absorption } \\
(\%)\end{array}$ & $\begin{array}{l}\text { Increase in absorption } \\
\text { percentages (\%) with } \\
\text { respect to A1 }\end{array}$ \\
\hline A1 & 2479 & 2567 & $\ldots$ & 3.5 & $\ldots$. \\
\hline A2 & 2131 & 2252 & 14 & 5.7 & 62.9 \\
\hline A3 & 1826 & 1997 & 26.3 & 9.4 & 168.6 \\
\hline A4 & 1630 & 1854 & 34.2 & 13.7 & 291.4 \\
\hline
\end{tabular}

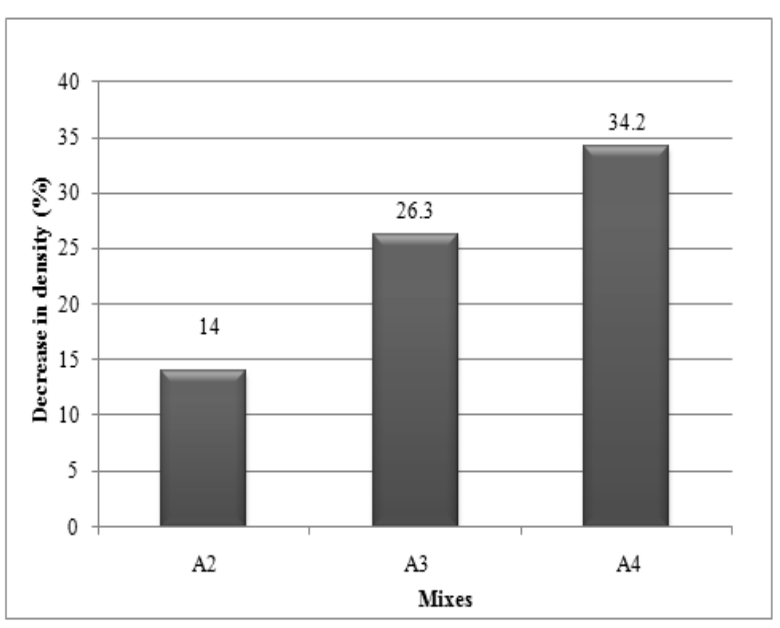

Figure 2: Drop in density $(\%)$ of the mixes that have volume fractions of replacing $(35 \%, 50 \%$ and 75$)$.

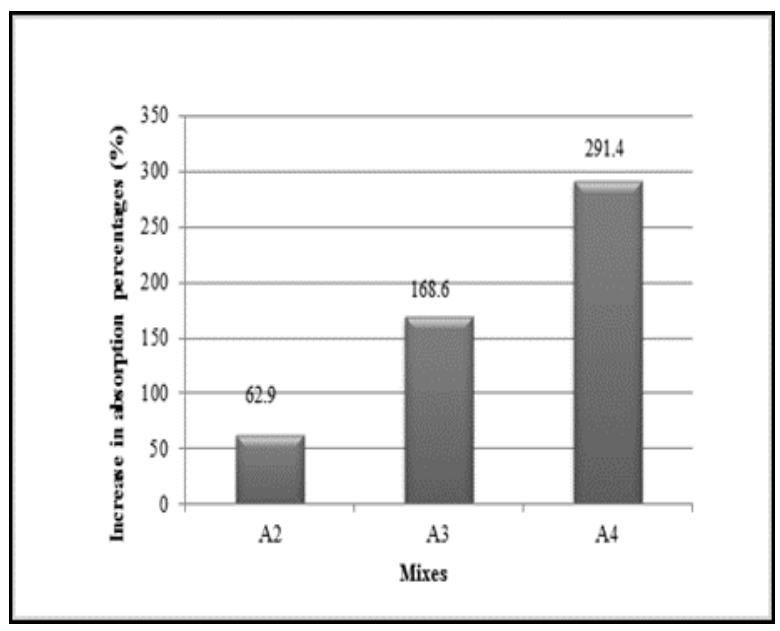

Figure 3: Increase in absorption capacity (\%) of the mixes that have volume fractions of replacing $(35 \%$, $50 \%$ and $75 \%$ ). 


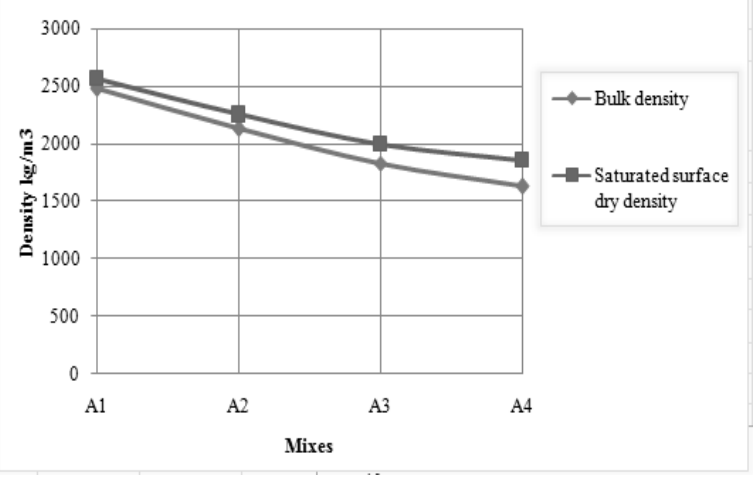

Figure 4: Density for all mixes

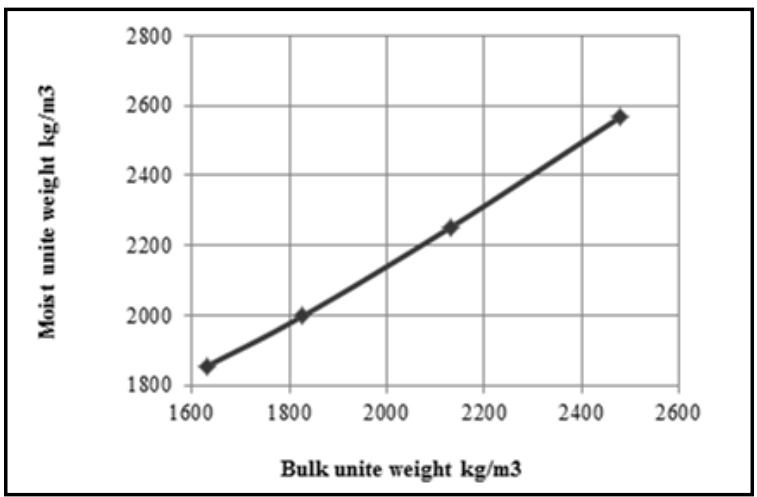

Figure 5: Relationship between bulk density and moist density for all mixes

\section{Compressive strength}

The compressive strength results of all mixes, are abridged in Table 10. For the different mixes the 28-day compressive strength varied from 11.5 $\mathrm{MPa}$ to $33.5 \mathrm{MPa}$. The important factor affected the strength is percentage replacement of natural coarse aggregate with cellular concrete aggregate. Figure 6 shows the diversity of compressive strength with cellular concrete aggregate replacement percentages where the compressive strength values at constant ratio $6 \%$ of SF have been plotted for the three cellular concrete aggregate replacement percentages in addition to the control mix ( $0 \%$ replacing cellular concrete aggregate) $(0 \% \mathrm{SF})$.The percentages of losing strength with respect to the control mix for $35 \%$, $50 \%$ and $75 \%$ of cellular concrete aggregate replacements are $21.1 \%, 32.4 \%$, and $65.7 \%$ respectively. In spite of use the SF with a constant value $(6 \%)$ in all mixes except the control mix the results denote that compressive strength decrease when increasing the percentage replacements of cellular concrete aggregate because the strength of cellular concrete that used as coarse aggregate is lighter than the natural coarse aggregate and the percentage of additional $\mathrm{SF}$ is not enough to compensate of strength reducing that caused by replaced the natural coarse aggregate with cellular concrete aggregate. Figure 7 shows the relation between the bulk density and compressive strength of all mixes of concrete. This graph demonstrates the trend of increasing strength with increasing density for concrete. The specimen A3 gives the best result for compressive strength and density because the compressive strength for this specimen $22.6 \mathrm{MPa}$ is greater than $17 \mathrm{MPa}$ that make it be used for structural applications [2] and the density for this specimen $(1826 \mathrm{~kg} / \mathrm{m} 3)$ is within the lightweight concrete ranges of 300 to $1850 \mathrm{~kg} / \mathrm{m} 3$ as defined by Neville[24]. Figure 8 depicts a cube during the compression test.

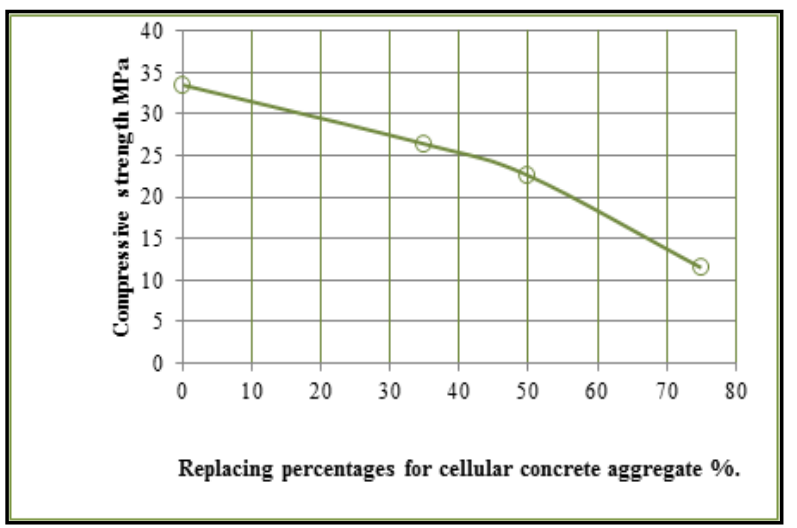

Figure 6: Relationship between compressive

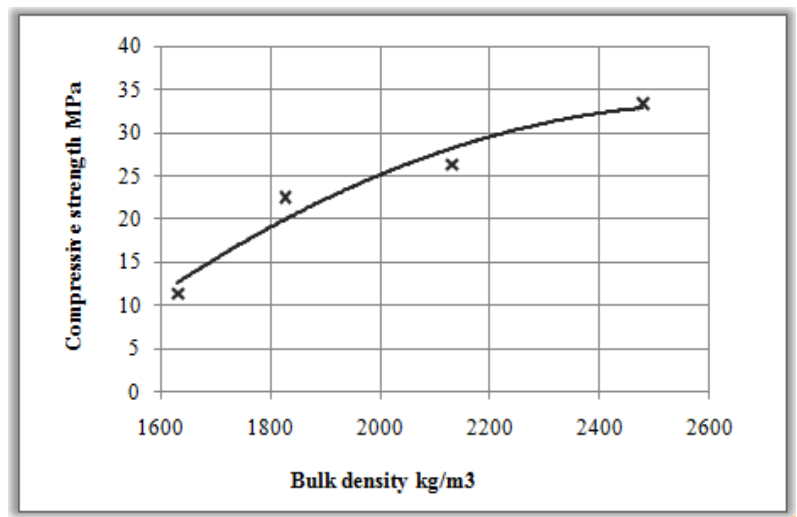

strength and percentage replacements of cellular concrete aggregate

Figure7: Relationship between the bulk density and compressive strength

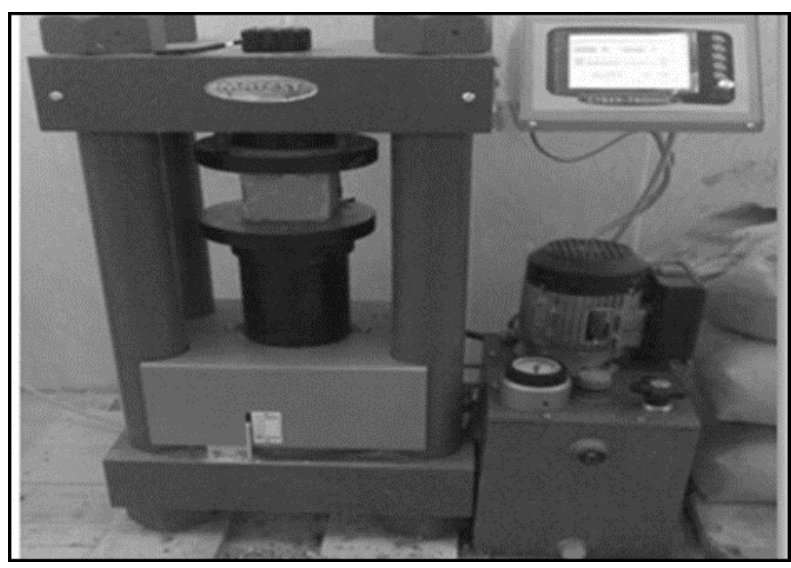


Figure 8: A cube during the compressive strength

test

Table 10: Compressive strength, splitting strength, flexural strength and Thermal Conductivity of concrete for specimens used at age 28 day

\begin{tabular}{lllllll}
\hline \hline Index & $\begin{array}{l}\text { Coarse aggregate } \\
\text { replacement with } \\
\text { recycled cellular } \\
\text { concrete aggregates }(\%)\end{array}$ & $\begin{array}{l}\text { Silica } \\
\text { fume } \\
(\mathrm{SF}) \%\end{array}$ & $\begin{array}{l}\text { Compressive } \\
\text { strength MPa }\end{array}$ & $\begin{array}{l}\text { Splitting } \\
\text { strength } \\
\mathrm{MPa}\end{array}$ & $\begin{array}{l}\text { Flexure } \\
\text { strength } \\
\mathrm{MPa}\end{array}$ & $\begin{array}{l}\text { Thermal } \\
\text { conductivity } \\
\text { w/m. k }\end{array}$ \\
\hline $\mathrm{A} 1$ & 0 & 0 & 33.5 & 2.8 & 6.4 & 1.6 \\
\hline $\mathrm{A} 2$ & 35 & 6 & 26.4 & 2.1 & 4 & 1.03 \\
\hline $\mathrm{A} 3$ & 50 & 6 & 22.6 & 1.9 & 3.6 & 0.7 \\
\hline $\mathrm{A} 4$ & 75 & 6 & 11.5 & 1.4 & 2.7 & 0.55 \\
\hline
\end{tabular}

\section{Splitting strength}

The results in Table 10 show that the splitting strength decrease when increasing the percentage of replacements of cellular concrete aggregate, Figure 9 displays the diversity of splitting strength with the cellular concrete aggregate replacement percentages. The loss of splitting strength is almost like a loss of compressive strength. The percentages of losing strength with respect to the control mix for $35 \%, 50 \%$, and $75 \%$ cellular concrete aggregate replacements are $25 \%, 32.1 \%$, and $50 \%$, respectively. The relation between the splitting strength and compressive strength of all mixes of concrete are shown in Figure 10.

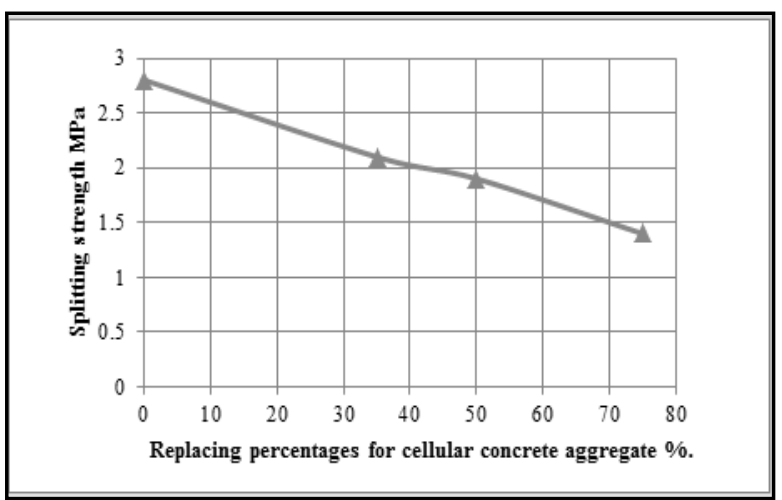

Figure 9: Relationship between splitting strength and percentage replacements of cellular concrete aggregate

Figure 10: Relationship between the splitting strength and compressive strength

IV. Flexural strength

The flexure strength of all mixes are explained in

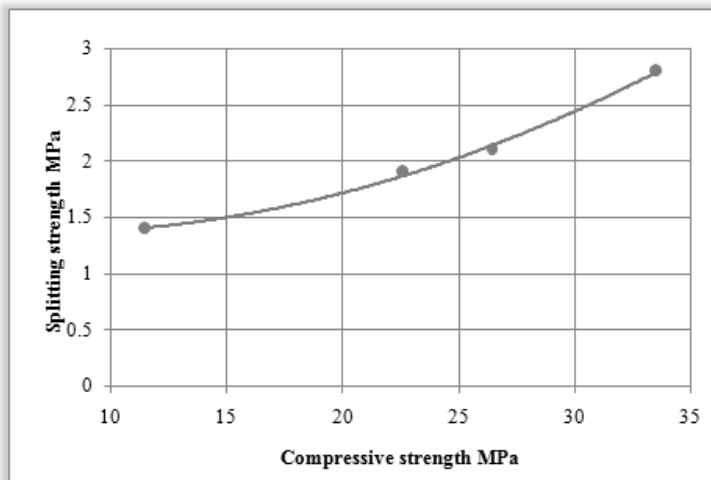

Table 10. Figure 11 shows the diversity of flexure strength with the cellular concrete aggregate replacement percentages. There is an obvious loss in flexure strength due to cellular concrete aggregate replacement

Figure 11: Relationship between flexure strength and percentage replacements of cellular concrete

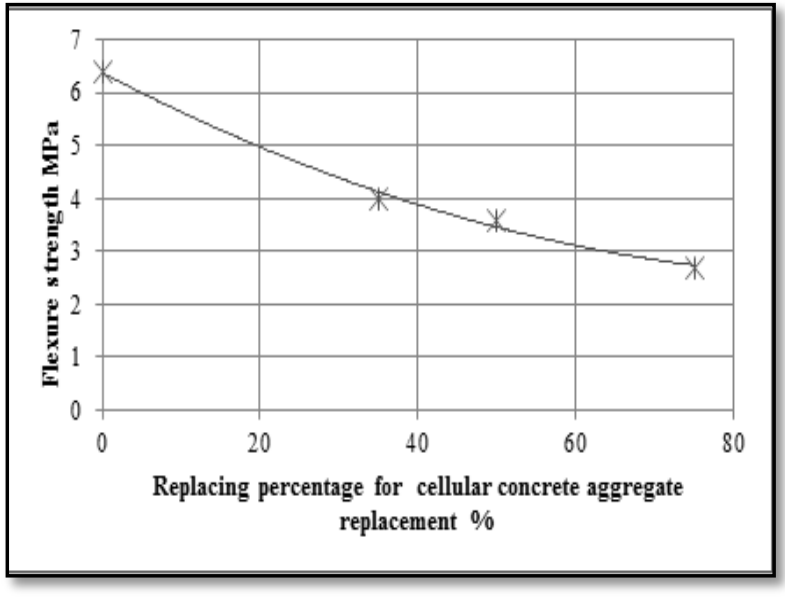

aggregate

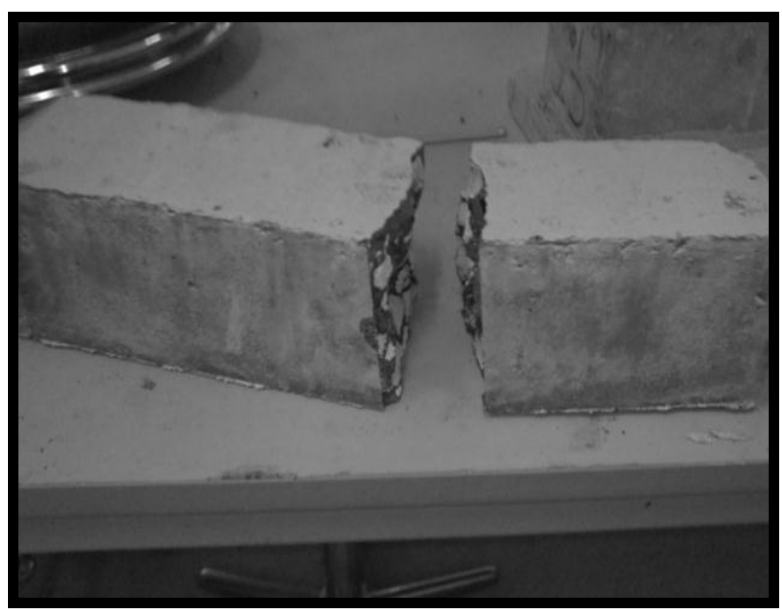

Figure 12: Shows a A4 beam after flexural strength test 


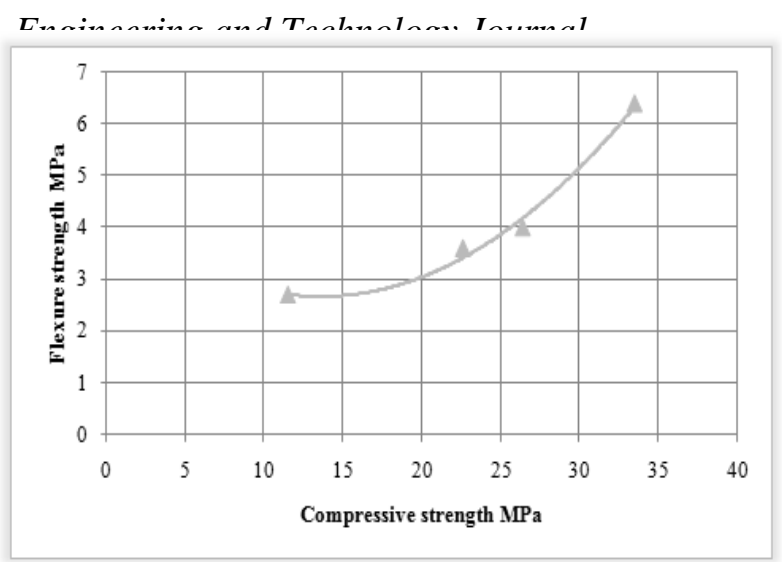

Figure 13: Relationship between the flexure strength and compressive strength

\section{$V$. Thermal conductivity}

It has been developed in several ways to compute the thermal conductivity of concrete. The determination of thermal conductivity of concrete is usually accrued according to ACI Committee 523 [25] by the equation (1). When test data are not ready these calculated evaluations are useful. This equation is often interrelated to dry density of concrete as a function of the logarithm of kc

$$
\mathrm{kc}=0.072 \times \mathrm{e}^{0.00125 \times \mathrm{d}}
$$

Where:

$\mathrm{kc}$ : thermal conductivity in $\mathrm{w} / \mathrm{m} \mathrm{k}$ $\mathrm{d}$ : dry density in $\mathrm{kg} / \mathrm{m}^{3}$

As a result, the various volume fractions of replacing the natural coarse aggregate $(35 \%, 50 \%$, and $75 \%$ ) by cellular concrete aggregate leads to decrease the thermal conductivity from $(35.4 \%$, $56 \%$, and $65 \%$ ) respectively as shown in Table 9 and Figure 14.

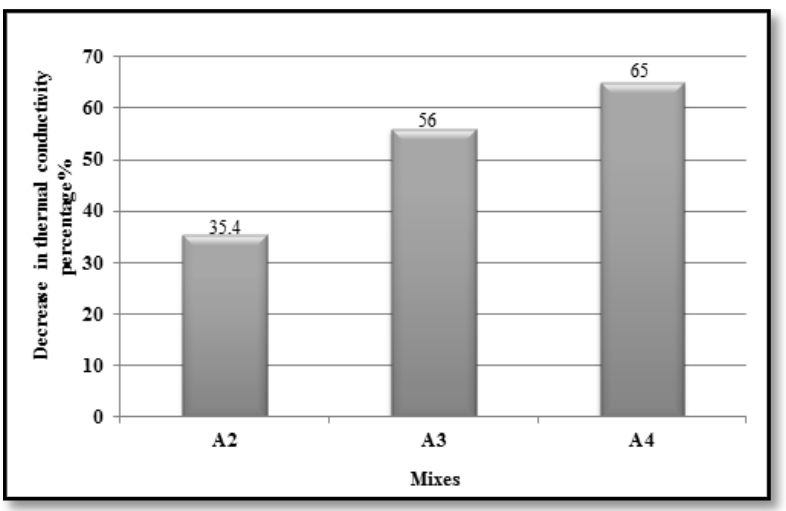

Figure14: The Drop in thermal conductivity (\%) of the mixes that have volume fractions of replacing $(35 \%, 50 \%$ and $75 \%)$

\section{Conclusions}

Through the experimental work carried out in this study, the following conclusions were reached: 1. The successful application of structural demolished elements lightweight can be used in structural lightweight concrete to improve green construction environment such as decreasing the wastes trade on site and keeping dust level at the construction site to the minimum.

2. The use of cellular concrete aggregate instead of natural coarse aggregate leads to decrease the density by $(14 \%, 26.3$ and $34.2 \%)$ and increase the rate of absorption by $(62.9 \%, 168.6 \%$, and $291.4 \%$ ) with difference percentages depends on the percentages of replacing $(35 \%, 50 \%$, and $75 \%)$ respectively.

3 . The replacing natural coarse aggregate $(35 \%$, $50 \%$, and $75 \%$ ) by cellular concrete aggregate leads to decrease the compressive strength because the strength of cellular concrete that used as coarse aggregate is lighter than the natural coarse aggregate, the percentages of losing strength with respect to the control mix are $21.1 \%, 32.4 \%$, and $65.7 \%$ respectively. Although uses the SF with a constant value $(6 \%)$ in all mixes except the control mix.

4. Various volume fractions of replacing the natural coarse aggregate $(35 \%, 50 \%$, and $75 \%)$ by cellular concrete aggregate lead to decrease the splitting strength by $(25 \%, 32.1 \%$, and $50 \%)$ respectively.

5 . The percentages of variation in flexure strength for $35 \%, 50 \%$ and $75 \%$ cellular concrete aggregate replacements percentages with respect to the control mix are $37.5 \%, 43.8 \%$, and $57.8 \%$, respectively, that is means the natural coarse aggregate replacement leads to decrease of flexure strength.

6. The trend in the flexure strength loss and splitting strength loss for three different cellular concrete aggregate replacement percentages in addition to the control mix are almost similar to that in compressive strength.

7. The thermal conductivity is decreased when increasing the percentage replacements of cellular concrete aggregate, the percentages of losing thermal conductivity with respect to the control mix for $35 \%, 50 \%$, and $75 \%$ cellular concrete aggregate replacements are $(35.4 \%, 56 \%$, and $65 \%$ ) respectively.

\section{Reference}


[1] T.W. Bremner, and J. Ries, "Stephen J. Hayde: Father of the Lightweight Concrete Industry," Concrete International, Vol. 31, No. 8, pp. 35-38, Aug. 2009.

[2] NRMCA, "Structural Lightweight Concrete," National ready mixed concrete association, 2003, Available: http://www.nrmca.org .

[3] G. Greene and B. Graybeal, "Lightweight Concrete: Mechanical Properties," Report No. FHWA-HRT-13-062, Federal Highway Administration, Washington, DC, 2013, Available: http://www.ntis.gov.

[4] CBDG, "Guide to the Use of Lightweight Aggregate Concrete in Bridges," Cement and concrete industry publication, Technical Guide No.8, 2006, Available: http://www.cbdg.org.uk.

[5] W.T. Huan, "Recent developments in lightweight high strength concrete with andwithout aggregates," 3rd International Conference on Construction Materials: Performance, Innovations and Structural Implications ,University of British Columbia, Vancouver. Canada, 2224 August 2005.

[6] H.C. Ozyildirim, "Laboratory Investigation of Lightweight Concrete Properties," VCTIR 11-R17. Virginia Center for Transportation Innovation and Research 530 Edgemont Road Charlottesville, VA 22903, April 2011, Available: http://www.virginiadot.org.

[7] C. Jeffrey "Construction and Demolition Waste; A Literature Review," Dalhousie University's Office of Sustainability, September, 2011, Available: https://cdn.dal.ca/content/dam/dalhousie/pdf/dept/sustainab ility/Final\%20C\%26D\%20literature\%20review.pdf.

[8] Y.L. Tommy and H.Z. Cui, "Properties of Green Lightweight Aggregate Concrete," International Workshop on Sustainable Development and Concrete Technology, Department of Building and Construction, City University of Hong Kong, HongKong, pp.113-118, 2004.

[9] M. H. Hussen, N. M. Fauzi and Z. M. Rauf, "Insulating Lightweight Aggregate Concrete," Eng. \&Tech. Journal, Vol.28, No.13, pp.678-691, 2010.

[10] E.T. Dawood, W.A. Abbas and Y.Z. Mohammad, "Proportioning of Foamed Concrete Reinforced with Carbon Fibers,” Eng. \&Tech. Journal, Vol. 34, Part (A), No.15, pp.2864-2876, 2016.

[11] K.G. Babu, D.S. Babu, "Behavior of Lightweight Expanded Polystyrene Concrete Containing Silica Fume," Cement and Concrete Research Journal, Vol. 33, No. 5, pp. 755-762, May 2003.

[12] B.G. Fonteboa, F.M. Abella, "Concretes with Aggregates from Demolition Waste and Silica Fume, Materials and Mechanical Properties," Building and Environment Journal, Vol. 43, No.4, pp.429-437, April 2008.

[13] B. Chen, J. Liu, "Properties of Lightweight Expanded Polystyrene Concrete Reinforced with Steel Fiber," Cement and Concrete Research Journal, Vol. 34, No. 7, pp.1259-1263, 2004.

[14] Iraqi specification No.5 (I.Q.S 5) "Portland Cement," Central Organization for Standardization and Quality Control, Bagdad, 1984.
[15] ASTM C 1240 "Standard Specification for Use of Silica Fume as a Mineral Admixture in Hydraulic-Cement Concrete, Mortar, and Grout,” July 2000.

[16] ASTM C330\03 "Standard Specification for Aggregates for Structural Concrete," American Society for Testing and Materials, 2003.

[17] ASTM C330: "Standard Specification for Lightweight Aggregates for Structural Concrete," American Society for Testing and Materials, 1999.

[18] ASTM C 796 " Standard Test Methods for Foaming Agents for Use in Producing Cellular Concrete Using Preformed Foam," 2004.

[19] ASTM C496/C496M "Standard Test Method for Splitting Tensile Strength of Cylindrical Concrete Specimens," 2004.

[20] ASTM C567 "Standard Test Method for Determining Density of Structural Lightweight Concrete," Book of Standards Volume 04.02, ASTM International, Conshohocken, PA, 2005.

[21] ASTM C642: "Standard Test Method for Density, Absorption, and Voids in Hardened Concrete," Philadelphia, 2006.

[22] ASTM C78 "Standard Test Method for Flexural Strength of Concrete (Using Simple Beam With ThirdPoint Loading)," 2008.

[23] British Standards Institute B.S 1881: Parts 116 "Method for Determination of Compressive Strength of Concrete Cubes," 1983.

[24] A.M. Neville, "Properties of Concrete," 4th ed., ELBS with Addison Wesley Longman, England, 1996.

[25] ACI Committee 523, "Guide for Cast -in -Place Low-Density Concrete," Journal of ACI Vol.83, pp830837, September- October 1986. 